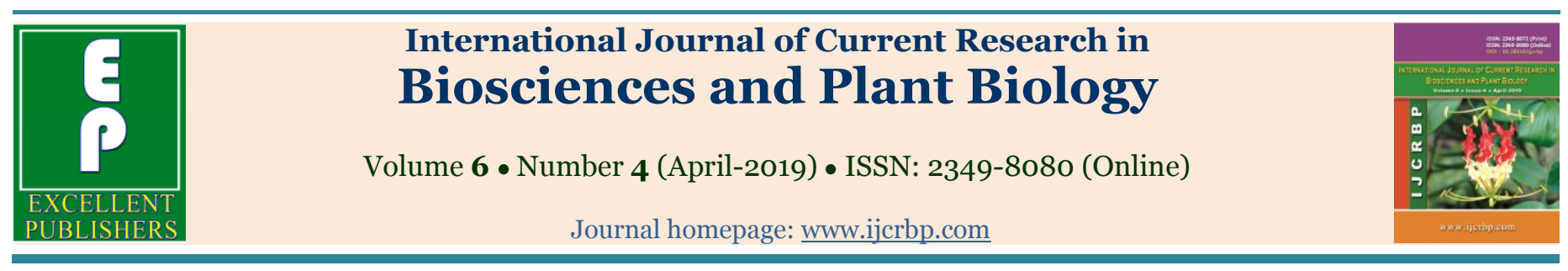

\title{
The effect of nutrients on the growth of microalgae Haematococcus lacustris (Girod-chantrans) Rostafinski 1875
}

\author{
Dang Mau TRINH ${ }^{*}$, Thi Trang NGUYEN, Phuoc Kha NGUYEN, \\ Nguyen Quynh Anh TRAN² and Chau Tuan VO'
}

\begin{abstract}
${ }^{1}$ Faculty of Biology and Environmental Sciences, The University of Danang - University of Education, Danang, Vietnam ${ }^{2}$ Faculty of Chemistry, The University of Danang - University of Education, Danang, Vietnam

*Corresponding author; e-mail: tdmau@ued.udn.vn, trinhdangmau@gmail.com
\end{abstract}

\begin{tabular}{|c|c|}
\hline e Info & ABSTRACT \\
\hline $\begin{array}{l}\text { Date of Acceptance: } \\
19 \text { March } 2019\end{array}$ & \multirow{8}{*}{$\begin{array}{l}\text { Haematococcus lacustris is capable to synthesize high content of astaxanthin. } \\
\text { Moreover, astaxanthin extracted from } H \text {.lacustris has been shown to have the highest } \\
\text { anti-oxidativeactivity. While the demand for astaxanthin in the world is increasing, the } \\
\text { production of astaxanthin from } H \text {. lacustris is still not easy since they have low growth } \\
\text { rate and are very sensitive to changes in culture conditions. This study aimed at } \\
\text { investigating the effect of nutritional factors on the growth rate of } H \text {. lacustris in order } \\
\text { to determine the optimal medium for the biomass growth and astaxanthin synthesis of } \\
\text { this specy. The results showed that } H \text {.lacustris grew better in } \mathrm{RM} \text { culture medium ( } 2.62 \\
\left. \pm 0.17 \times 10^{5} \text { cells } / \mathrm{ml}\right) \text { than in } \mathrm{BBM} \text { culture medium }\left(2.44 \pm 0.10 \times 10^{5} \text { cells } / \mathrm{ml}\right) \text {. The } \\
\text { highest cell density of } \mathrm{H} \text {. lacustris was achieved in the RM medium with } \mathrm{NaNO}_{3} \text { at } 1200 \\
\mathrm{mg} / \mathrm{l}\left(3.72 \pm 0.022 \times 1 \mathrm{O}^{5} \mathrm{cell} / \mathrm{ml}\right) \text {, and in the } \mathrm{RM} \text { medium with } \mathrm{K}_{2} \mathrm{HPO}_{4} \text { at } 32 \mathrm{mg} / \mathrm{l} \\
\left(3.42 \pm 0.05 \times 10^{5} \text { cells } / \mathrm{ml}\right) \text {. }\end{array}$} \\
\hline $\begin{array}{l}\text { Date } \\
\mathrm{o} 6 \mathrm{~A}_{\mathrm{I}}\end{array}$ & \\
\hline Key & \\
\hline & \\
\hline & \\
\hline & \\
\hline & \\
\hline & \\
\hline
\end{tabular}

\section{Introduction}

Astaxanthin (3, 3'- dihydroxy $\beta, \beta^{\prime}$ carotene - 4,4 dione) is a keto-carotenoid found in a variety of seafoods such as salmon, shrimp, crabs, fish eggs (Hagen et al., 2002). Its antioxidant activity is 10 times higher than other carotenoids such as $\beta$ carotene, zeaxanthin, lutein, canthaxanthin and even 500 times higher than a-tocopherol (Olaizola, 2000). Due to its capacity of blocking certain types of cancer and stimulating the immune system to be superior to B-carotene and a-tocopherol, astaxanthin is increasingly applied in the field of medicine and pharmacy (Nguyen and Nguyen, 2014; Dang et al.,
2010). Furthermore, astaxanthin is widely used in the food industry and aquaculture. For example, it is used as a type of food for salmon to enhance the color of fish meat - an important quality parameter for consumer's choice (Gouveia et al., 2003; Gouveia and Rema, 2005; Torrissen, 2000).

Currently, the demand for astaxanthin in the world is increasing. However, astaxanthin supplies are mainly from chemical synthesis (accounting for 95\%). This source of astaxanthin is very expensive, but its biological activity is rather low. Haematococcus lacustris, a species of green algae (Chlorophyta), has a high astaxanthin 
accumulation capacity, reaching $5-6 \%$ its dry weight (Bubrick, 1991; Cifuentes et al., 2003). Moreover, $100 \%$ of astaxanthin extracted from $H$. lacustris is in the form of $3 \mathrm{~S}-3$ 'S isomers, which provides the highest levels of antioxidant activity (Lorenz and Cysewsko, 2000). Therefore, the production of astaxanthin from $H$. lacustris has attracted much research interest.

Meanwhile, the production of astaxanthin from $H$. lacustris is still not easy since they have a low growth rate and are susceptible to changes in culture conditions. When cultured under appropriate conditions, most of the microalgal cells remain in vegetative state, which does not accumulate astaxanthin or accumulate with a low content. Under stress conditions, the algae cell will convert to a nonmoving cyst, and they can accumulate large amounts of astaxanthin when appropriately stimulated. Therefore, the conditions for algae cell to grow and synthesize astaxanthin are very different. This study aimed at investigating the effect of nutritional factors on the growth rate of $H$. lacustris in order to determine the optimal medium for the biomass growth and astaxanthin synthesis of this species.

\section{Materials and methods}

$H$. lacustris was acquired from the Faculty of Biotechnology, Vietnam National University of Agriculture. The stock culture and the inoculum were grown in the Bold Basal Medium (BBM) (Andersen, 2005). The inoculum was grown aseptically in a $700 \mathrm{ml}$ flasks containing $400 \mathrm{ml}$ of BBM medium with a stable temperature of $25^{\circ} \mathrm{C}$, $16 \mathrm{~h}$ light:8 h dark cycle of $30 \mu \mathrm{mol}$ photon $\mathrm{m}^{-2} \mathrm{~s}^{-1}$ white fluorescent light.

\section{Investigate the effect of Sodium nitrate concentration on the growth of $H$. lacustris}

The experiment was carried out with an initial algae density of $1.07 \times 10^{4}$ cells / ml inserted into a $50 \mathrm{ml}$ BBM and RM culture media, a luminous intensity of $30 \mu \mathrm{mol}$ photon $\mathrm{m}^{-2} \mathrm{~s}^{-1}$, at a stable temperature of $25 \pm 0.5^{\circ} \mathrm{C}$ on a $16: 8$ dark-light cycle. The growth of $H$. lacustris was tested on two mediums BBM and RM, which had different concentrations of Sodium nitrate (Table 1). The growth rate of $H$. lacustris was assessed at a frequency of 2 days.

Table 1. Experimental design to investigate the effect of sodium nitrate concentration on the growth of $H$. lacustris.

\begin{tabular}{llll}
\hline RM culture medium & & BBM culture medium & \\
\hline $\mathbf{N a N O}_{\mathbf{3}}$ concentration & Number of sample & $\mathbf{N a N O}_{\mathbf{3}}$ concentration & Number of sample \\
\hline $300 \mathrm{mg} / \mathrm{l}$ & 3 bottles & $250 \mathrm{mg} / \mathrm{l}$ & 3 bottles \\
$600 \mathrm{mg} / \mathrm{l}$ & 3 bottles & $500 \mathrm{mg} / \mathrm{l}$ & 3 bottles \\
$900 \mathrm{mg} / \mathrm{l}$ & 3 bottles & $750 \mathrm{mg} / \mathrm{l}$ & 3 bottles \\
$1200 \mathrm{mg} / \mathrm{l}$ & 3 bottles & $1000 \mathrm{mg} / \mathrm{l}$ & 3 bottles \\
$1500 \mathrm{mg} / \mathrm{l}$ & 3 bottles & $1250 \mathrm{mg} / \mathrm{l}$ & 3 bottles \\
$1800 \mathrm{mg} / \mathrm{l}$ & 3 bottles & $1500 \mathrm{mg} / \mathrm{l}$ & 3 bottles \\
\hline
\end{tabular}

Investigate the effect of dipotassium phosphate concentration on the growth of H. lacustris

Experimental conditions to assess the effect of dipotassium phosphate concentration on the growth of $H$. lacustris were designed the same as those for sodium nitrate. The only difference was that the BBM and RM media had different concentrations of dipotassium phosphate).

Table 2. Experimental design to investigate the effect of dipotassium phosphate concentration on the growth of H. lacustris.

\begin{tabular}{llll}
\hline $\mathbf{R M}$ culture medium & & BBM culture medium & \\
\hline $\begin{array}{l}\mathbf{K}_{\mathbf{2}} \mathbf{H P O} \\
\text { concentration }\end{array}$ & Number of sample & $\mathbf{K}_{\mathbf{2}} \mathbf{H P O} \mathbf{4}$ concentration & Number of sample \\
\hline $80 \mathrm{mg} / \mathrm{l}$ & 3 bottles & $100 \mathrm{mg} / \mathrm{l}$ & 3 bottles \\
$160 \mathrm{mg} / \mathrm{l}$ & 3 bottles & $200 \mathrm{mg} / \mathrm{l}$ & 3 bottles \\
$240 \mathrm{mg} / \mathrm{l}$ & 3 bottles & $300 \mathrm{mg} / \mathrm{l}$ & 3 bottles \\
$320 \mathrm{mg} / \mathrm{l}$ & 3 bottles & $400 \mathrm{mg} / \mathrm{l}$ & 3 bottles \\
$400 \mathrm{mg} / \mathrm{l}$ & 3 bottles & $500 \mathrm{mg} / \mathrm{l}$ & 3 bottles \\
$480 \mathrm{mg} / \mathrm{l}$ & 3 bottles & $600 \mathrm{mg} / \mathrm{l}$ & 3 bottles \\
\hline
\end{tabular}




\section{Determination of growth rate}

Cell density was counted under the microscope by the Neubauer counting chamber, and calculated according to the following formula:

$$
D=\frac{A}{X} \times 10^{4}
$$

Where:

D: Cell concentration (cell $/ \mathrm{ml}$ ),

A: Total number of cells counted (cell),

$\mathrm{X}$ : Number of squares.

\section{Statistical analyses}

Data analysis was performed on the Microsoft Excel 2013 software. The statistical significance of the differences between groups was assessed by one-factor analysis of variance (Anova One way).

\section{Results and discussion}

\section{The effect of Sodium nitrate concentration on the growth of $H$. lacustris}

Nitrate concentration was identified as the best source of nitrogen for the growth of microalgae cell (Yuan and Chen, 2001). Furthermore, it has the ability to prolong the vegetative state of microalgae (Ranjbar et al., 2008). That is the reason why we conducted the experiments to investigate the effect of nitrate concentration on the growth rate of $H$. lacustris in BBM and RM media. In RM medium, the results showed that at a concentration of 1200 $\mathrm{mg} / \mathrm{L} \mathrm{NaNO}_{3}$, the highest cell density was recorded after 18 days culture with $3.72 \pm 0.022 \times 10^{5}$ cells $/ \mathrm{mL}$, with a peak growth rate of $0.2 \mu$. The highest cell densities at $\mathrm{NaNO}_{3}$ concentrations of $1800 \mathrm{mg} / \mathrm{L}, 1500 \mathrm{mg} / \mathrm{L}, 900 \mathrm{mg} / \mathrm{L}, 600 \mathrm{mg} / \mathrm{L}$, and $300 \mathrm{mg} / \mathrm{L}$ were $3.48 \pm 0.051 \times 10^{5}, 3.27 \pm 0.083 \times$ $10^{5}, 2.86 \pm 0.230 \times 10^{5}, 2.70 \pm 0.055 \times 10^{5}$, and $2.62 \pm 0.017 \times 10^{5}$ cells $/ \mathrm{mL}$, respectively (Fig. 1). According to Thom et al. (2013), the algae cell reached at the highest density $\left(1.74 \times 10^{6}\right.$ cells $\left./ \mathrm{mL}\right)$ at the $\mathrm{NaNO}_{3}$ concentration of $876 \mathrm{mg} / \mathrm{L}$. However, in Thom's study, the time for the algae to reach the highest density was 36 days and the peak growth rate was $0.03 \mu$. The highest density in this study is lower than in other studies due to the initial algal cell density $\left(0.1 \times 10^{5}\right.$ cell $/ \mathrm{mL}$ in this study compared to $0.5 \times 10^{5} \mathrm{cell} / \mathrm{mL}$ to $1.74 \times 10^{6} \mathrm{cell} / \mathrm{mL}$ in other studies). However, the growth rate peaked in the survey is higher ( $0.2 \mu$ compared with $0.03 \mu$ compared with other studies). Furthermore, the initial stocking density may be one of the factors affecting the growth of $H$. lacustris.

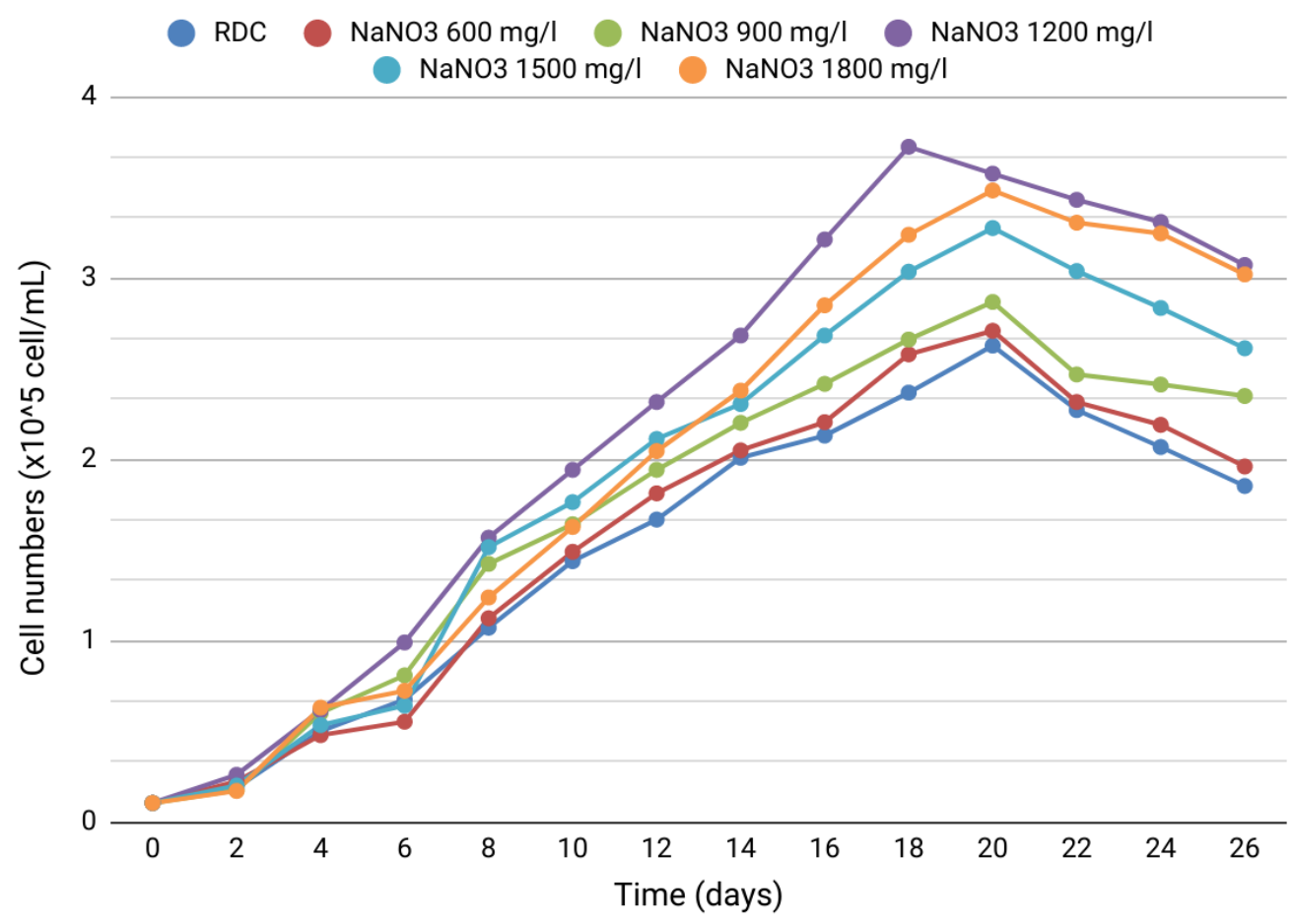

Fig. 1: The cell density of $H$. lacustris cultured in RM medium with different concentrations of $\mathrm{NaNO}_{3}$. 
In BBM medium, the highest cell density of the algae was obtained at $\mathrm{NaNO}_{3}$ concentration of $1000 \mathrm{mg} / \mathrm{L}$ with $3.46 \pm 0.030 \times 10^{5}$ cells $/ \mathrm{mL}$ at day $2 \mathrm{O}^{\text {th }}$, with the peak growth rate of $0,168 \mu$. At $\mathrm{NaNO}_{3}$ concentrations of $1500 \mathrm{mg} / \mathrm{L}, 1250 \mathrm{mg} / \mathrm{L}$,
$750 \mathrm{mg} / \mathrm{L}, 500 \mathrm{~g} / \mathrm{ml}$ and $250 \mathrm{mg} / \mathrm{L}$ (control medium), the highest density of microalgae cells were $3.31 \pm 0.07 \times 10^{5}, 3.14 \pm 0.04 \times 10^{5}, 2.75 \pm$ $0.2 \times 10^{5}, 2.59 \pm 0.06 \times 10^{5}, 2.44 \pm 0.1 \times 10^{5}$ cells/mL (Fig. 2).

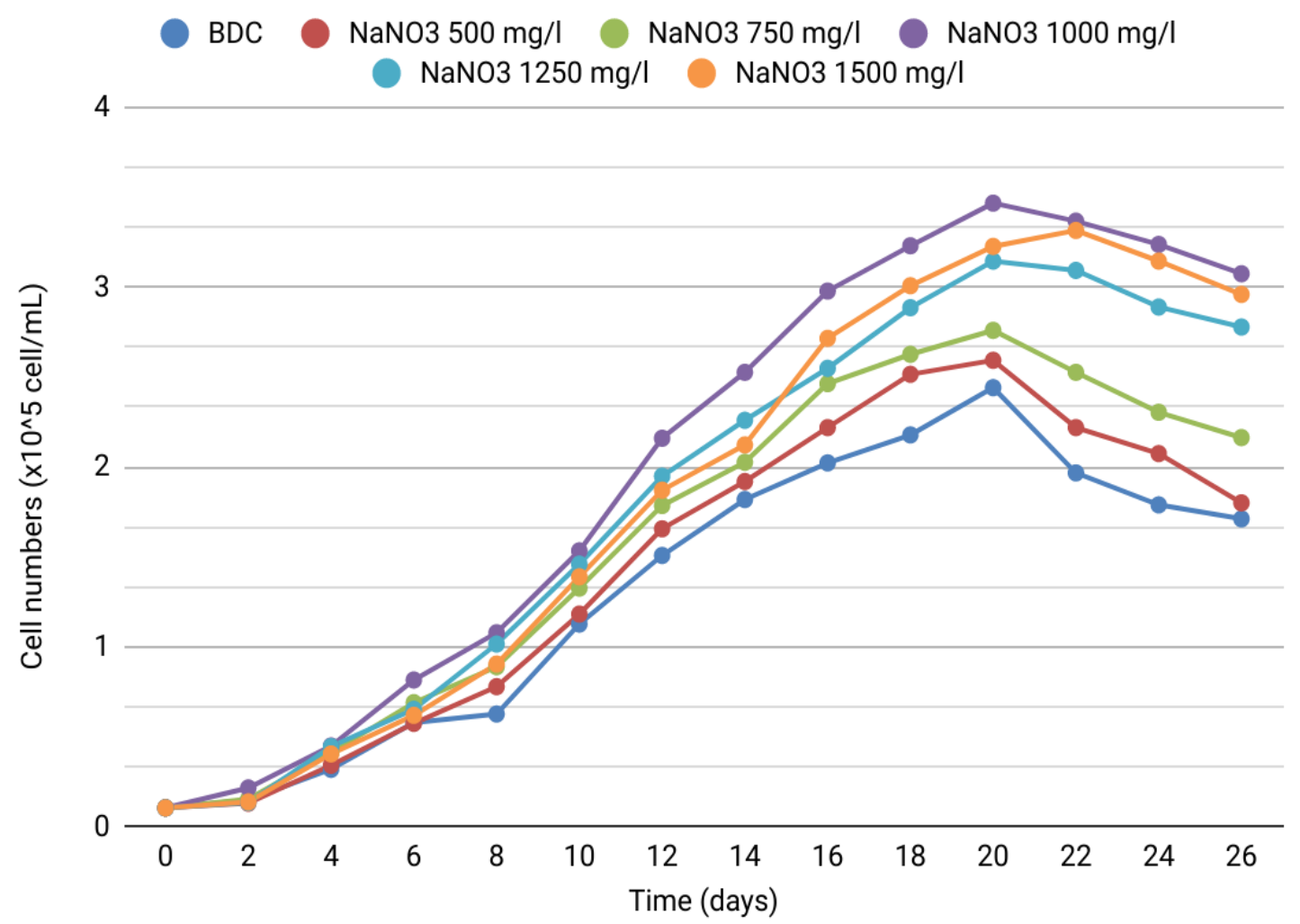

Fig. 2: The cell density of $H$. lacustris cultured in BBM medium with different concentrations of $\mathrm{NaNO}_{3}$.

All treatmentsin both BBM and RM media had a positive effect on the increase of $H$. lacustris cell density in comparison to the control medium. However, it should be noted that algae cell density did not increase linearly with the increase of $\mathrm{NaNO}_{3}$ concentration. The highest cell density in RM media at $\mathrm{NaNO}_{3}$ concentrations of $1400 \mathrm{mg} / \mathrm{L}$ and $1800 \mathrm{mg} / \mathrm{L}$ $\left(3.27 \pm 0.083 \times 10^{5}\right.$ cells $/ \mathrm{mL}$ and $3.48 \pm 0.051 \times$ $10^{5}$ cells $/ \mathrm{mL}$, respectively) were lower than that at $\mathrm{NaNO}_{3}$ concentrations of $1200 \mathrm{mg} / \mathrm{L}(3.72 \pm$ $0.022 \times 10^{5}$ cells $\left./ \mathrm{mL}\right)$. Similarly, in $\mathrm{BBM}$ medium, the highest cell density $(3.46 \pm 0.03 \times$ $10^{5}$ cells $/ \mathrm{mL}$ ) was obtained at $1000 \mathrm{mg} / \mathrm{L}$ of $\mathrm{NaNO}_{3}$ concentration, not at the higher concentrations of $\mathrm{NaNO}_{3}(1250 \mathrm{mg} / \mathrm{L}$ or 1500 $\mathrm{mg} / \mathrm{L}$ ). Moreover, the results also showed that increasing nitrogen concentration in the RM medium gave better results than in the BBM medium, with the growth rate of $0.2 \mu(\mathrm{RM})$ in comparison to $0.168 \mu(\mathrm{BBM})$. This might be explained by the difference in the nitrogen source in the two media. The RM medium contained two nitrogen sources for microalgae growth, that are $\mathrm{NO}_{3}^{-}$and $\mathrm{N}^{-} \mathrm{NH}_{4}{ }^{+}$; while the BBM medium had only one nitrogen supply, which is $\mathrm{NO}_{3}^{-}$.

\section{The effect of dipotassium phosphate concentration on the growth of $H$. lacustris}

Phosphorus is one of the main sources of nutrients for the growth and development of microalgae. It is necessary to investigate exactly the content of phosphorus giving the best growth and development for microalgae. This experiment examined the growth of $H$. lacustris in $\mathrm{RM}$ and $\mathrm{BBM}$ media at different $\mathrm{K}_{2} \mathrm{HPO}_{4}$ 
concentration. In RM medium, the best result was obtained at the $\mathrm{K}_{2} \mathrm{HPO}_{4}$ concentration of 320 $\mathrm{mg} / \mathrm{L}$. At this level of concentration, cell density of the microalgae was highest with $3.42 \pm 0.05 \times$ $10^{5}$ cells $/ \mathrm{mL}$ at day $22^{\text {nd }}$, and the peak growth rate was $0.15 \mu$. At $\mathrm{K}_{2} \mathrm{HPO}_{4}$ concentrations of 480 $\mathrm{mg} / \mathrm{L}$ and $400 \mathrm{mg} / \mathrm{L}$, the highest densities were
$3.12 \pm 0.02 \times 10^{5}$ and $2.94 \pm 0.04 \times 10^{5}$ cells $/ \mathrm{mL}$, respectively, at day $22^{\text {nd }}$. For the remaining concentrations $[240 \mathrm{mg} / \mathrm{l}, 160 \mathrm{mg} / \mathrm{l}$ and control medium (RDC)], the highest cell densities were $2.86 \pm 0.13 \times 10^{5}, 2.76 \pm 0.03 \times$ $10^{5}, 2.62 \pm 0.02 \times 10^{5}$ cells $/ \mathrm{mL}$, and recorded on day $20^{\text {th }}$ (Fig. 3).
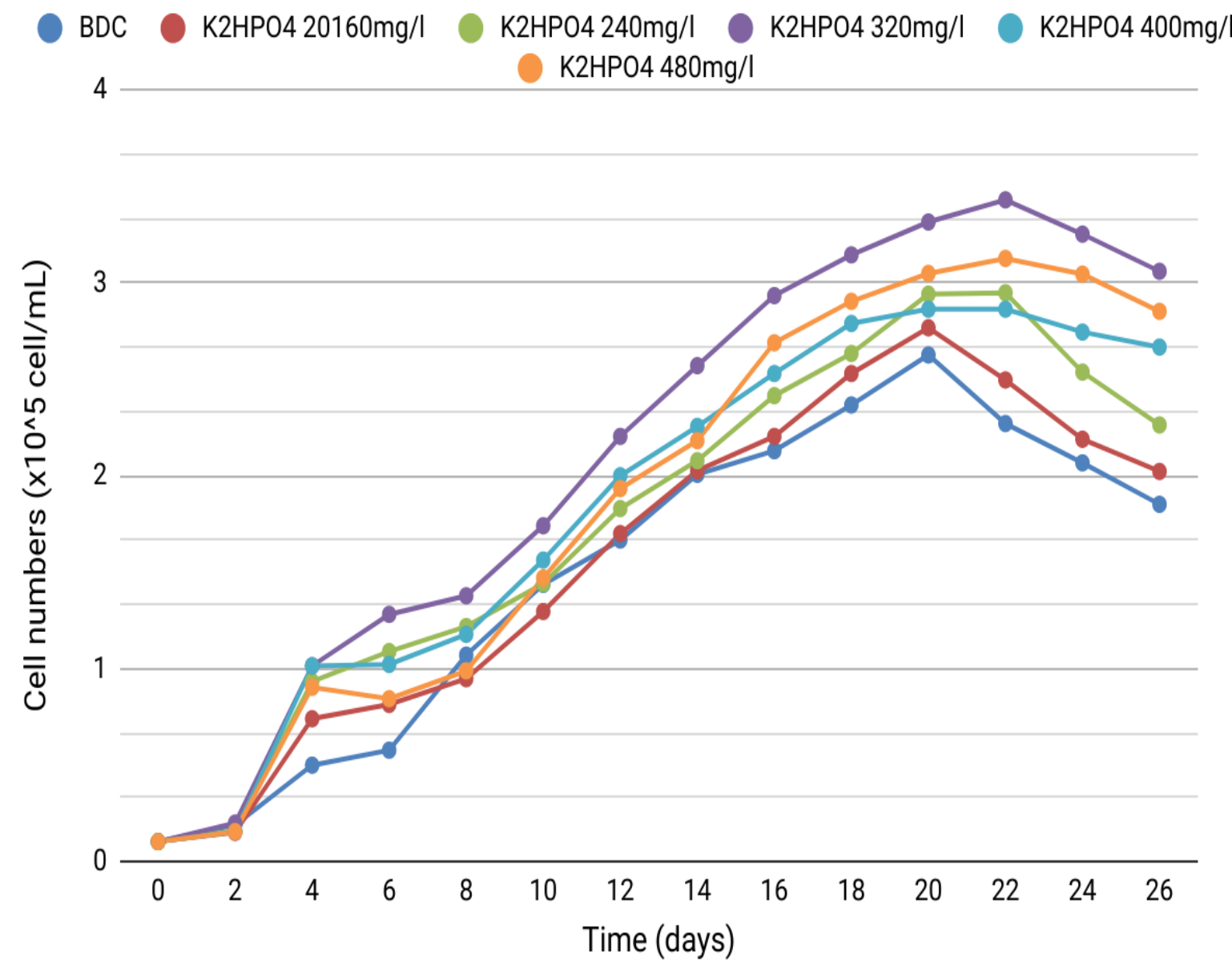

Fig. 3: The cell density of $H$. lacustris cultured in $\mathrm{RM}$ medium with different concentrations of $\mathrm{K}_{2} \mathrm{HPO}_{4}$.

Experimental results on $\mathrm{BBM}$ medium showed that concentration of $\mathrm{K}_{2} \mathrm{HPO}_{4}$ at $400 \mathrm{mg} / \mathrm{L}$ gave the highest increase in $H$. lacustris cell density compared with other concentrations. At this concentration level, $H$. lacustris had the highest cell density of $3.11 \pm 0.4 \times 10^{5}$ cells $/ \mathrm{mL}$ on day $22^{\text {nd }}$, with the peak growth rate of $0.14 \mu$. This cell density level was $27 \%$ higher than that in the control medium $\left(2.44 \pm 0.14 \times 10^{5}\right.$ cells $\left./ \mathrm{mL}\right)$, and also higher than that $\left(2.54 \pm 0.023 \times 10^{5}, 2.59 \pm 0.08 \times\right.$ $\left.10^{5}, 2.77 \pm 0.06 \times 10^{5}, 2.91 \pm 0.03 \times 10^{5} \mathrm{cells} / \mathrm{mL}\right)$ in other $\mathrm{K}_{2} \mathrm{HPO}_{4}$ concentrations $(375 \mathrm{mg} / \mathrm{L}, 475 \mathrm{mg} / \mathrm{L}$, $675 \mathrm{mg} / \mathrm{L}$, and $775 \mathrm{mg} / \mathrm{L}$ ) (Fig. 4).
The initial cell density at different concentrations of $\mathrm{K}_{2} \mathrm{HPO}_{4}$ on different media affected the growth of microalgae $H$. lacustris. However, cell density did not increase linearly with the increase of $\mathrm{K}_{2} \mathrm{HPO}_{4}$ concentrations in the media. The growth of microalgae $H$. lacustris was restricted when $\mathrm{K}_{2} \mathrm{HPO}_{4}$ concentration was higher than $320 \mathrm{mg} / \mathrm{L}$ in RM medium, and 400 $\mathrm{mg} / \mathrm{L}$ in BBM medium. Besides, the growth of $H$. lacustris in different $\mathrm{K}_{2} \mathrm{HPO}_{4}$ concentration in RM medium was better than in BBM medium (the peak growth rate $0.15 \mu$ in comparison with $0.14 \mu)$. 

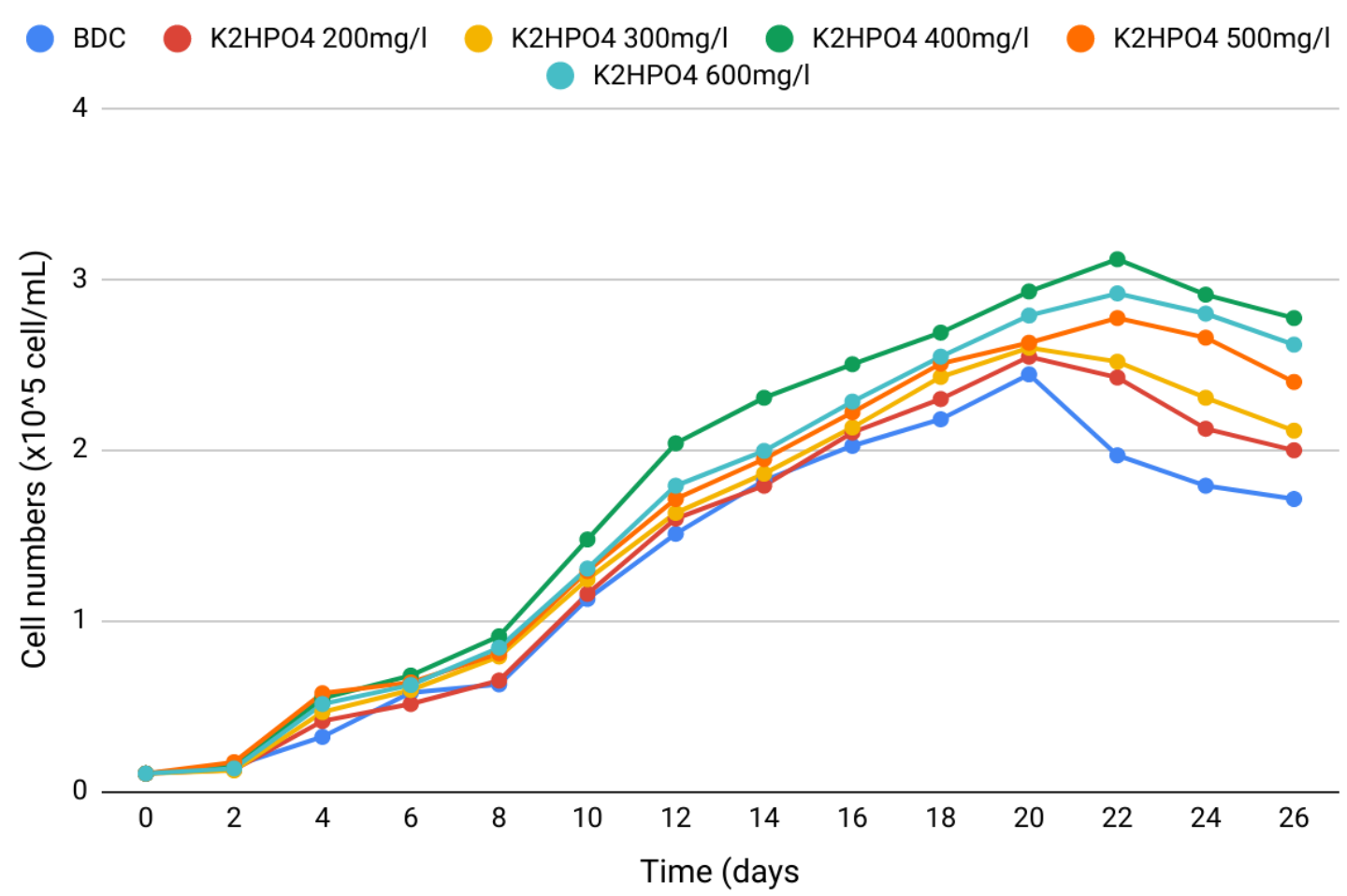

Fig. 4: The cell density of $H$. lacustris cultured in BBM medium with different concentrations of $\mathrm{K}_{2} \mathrm{HPO}_{4}$.

\section{Conclusion}

The results showed that RM culture media was more suitable than BBM media for the growth and development of the microalgae $H$. lacustris. In the $\mathrm{RM}$ media, $H$. lacustris gave the best growth at $\mathrm{NaNO}_{3}$ concentration $1200 \mathrm{mg} / \mathrm{L}$, with cell density up to $3.72 \times 10^{5}$ cells $/ \mathrm{mL}$, which was 4.2 times higher than the control medium $\left(2.62 \times 10^{5}\right.$ cells $/ \mathrm{mL}$ ). The concentration of $\mathrm{K}_{2} \mathrm{HPO}_{4}$ at 320 $\mathrm{mg} / \mathrm{L}$ was the best for the growth of the microalgae was best. At this level of concentration, the highest density of $H$. lacustris reached $3.42 \pm 0.05 \times 10^{5}$ cells/mL. However, in this study, we only assessed the independent effects of nitrogen and phosphorus on the growth of $H$. lacustris. In fact, the appropriate ratio of nitrogen and phosphorus is an important factor influencing the growth and development of $H$. lacustris. Therefore, more detailed surveys on the effect of nitrogen and phosphorus ratios in culture media on the growth and development of $H$. lacustris should be implemented in near future.

\section{Conflict of interest statement}

Authors declare that they have no conflict of interest.

\section{Acknowledgement}

This study was supported by Research and teaching group on Environment and Biological Resources (DN-EBR), Da Nang University; Applied Biology Research Group (ABR), Faculty of Biology and Environmental Science, The University of Science and Education, Da Nang University.

\section{References}

Andersen, R.A. (Ed.), 2005. Algal Culturing Techniques. Elsevier.

Bubrick, P., 1991. Production of astaxanthin from Haematococcus. Bioresour. Technol. 38(2-3), 237-239.

Cifuentes, A.S., Gonzalez, M.A., Vargas, S., Hoeneisen, M., Gonzalez, N., 2003. Optimization of biomass, total carotenoids and astaxanthin production in Haematococcus pluvialis Flotow strain Steptoe (Nevada, USA) under laboratory conditions. Biol. Res. 36(3-4), 343-357.

Dang D. H., Dinh D. H., Nguyen T. T., Anh, H. T. L., 2010. Selection of optimal environment for cultivation of astaxanthin-rich Haematococcus pluvialis. Acad. J. Biol. 32(2), 43-53. (Vietnamese). 
Gouveia, L., Rema, P., 2005. Effect of microalgal biomass concentration and temperature on ornamental goldfish (Carassius auratus) skin pigmentation. Aquacult Nutr. 11(1), 19-23.

Gouveia, L., Rema, P., Pereira, O., Empis, J., 2003. Colouring ornamental fish (Cyprinus carpio and Carassius auratus) with microalgal biomass. Aquacult. Nutr. 9(2), 123-129.

Hagen, C., Siegmund, S., Braune, W., 2002. Ultrastructural and chemical changes in the cell wall of Haematococcus pluvialis (Volvocales, Chlorophyta) during aplanospore formation. Eur. J. Phycol. 37(2), 217-226.

Lorenz, R.T., Cysewski, G.R., 2000. Commercial potential for Haematococcus microalgae as a natural source of astaxanthin. Trend. Biotechnol. 18(4), 160-167.

Nguyen D. B., Nguyen T. T., 2014. Microalgae biotechnology: Prospects and challenges. Vietnam Sci. Technol. J. (8/651), 11. (Vietnamese)

Olaizola, M., 2000. Commercial production of astaxanthin from Haematococcus pluvialis using 25,000-liter outdoor photobioreactors. J. Appl. Phycol. 12(3-5), 499-506.

Ranjbar, R., Inoue, R., Shiraishi, H., Katsuda, T., Katoh, S., 2008. High efficiency production of astaxanthin by autotrophic cultivation of Haematococcus pluvialis in a bubble column photobioreactor. Biochem. Eng. J. 39(3), 575580.

Torrissen, O. J., 2000. Dietary delivery of carotenoids. In: Antioxidants in Muscle Foods: Nutritional Strategies to Improve Quality (Eds.: Decker, Eric, Faustman, Cameron, Lopez, B., Clemente, J.). John Wiley \& Sons, New York. 281p.

Thom, L. T., Mai, D. N., Anh, H. T. L., Thu, N. T. H., Ha, N. C., Hong, D. D., 2013. Effect of nitrate concentration on growth of green microalga Haematococcus pluvialis under laboratory conditions. Acad. J. Biol. 35(2), 219226.

Yuan, J.P., Chen, F., 2001. Kinetics for the reversible isomerization reaction of transastaxanthin. Food Chem. 73(2), 131-137.

\section{How to cite this article:}

Trinh, D. M., Nguyen, T. T., Nguyen, P. K., Tran, N. Q. A., Vo, C. T., 2019. The effect of nutrients on the growth of microalgae Haematococcus lacustris (Girod-chantrans) Rostafinski 1875. Int. J. Curr. Res. Biosci. Plant Biol. 6(4), 17-23. doi: https://doi.org/10.20546/ijcrbp.2019.604.003 